important in the remoter outcome period. However, in the short term the two are virtually identical. Differences might arise in the longer term, and outcome measures could provide further criteria for determining whether there is a binary distribution of outcome or, whatever the follow-up measures employed, this had a unimodal distribution. However, this was outside the modest remit of our own study, although it could be looked at in the future. Thus the inference drawn by Eagles that "these findings provide no convincing evidence for the dualist theory of the classification of depressive illness' is clearly not supported by the evidence and is therefore inappropriate.

M. W. P. CARNEY Northwick Park Hospital \& Clinical Research Centre Watford Road Harrow, Middlesex

E. H. REYNoLDS
B. ToONE

\section{The Hungerford Massacre and its Aftermath}

SIR: The above hypereredic* episode has received world-wide publicity. The unanticipated consequences of such attention seem worthy of closer observation, as does the possibility of prevention in some instances of this type of explosive behaviour.

During the 1950 s and 1960 s I examined hypereredic individuals categorised in this area as 'amok runners'. They came from among peoples of three grades of technological development: the Melanesians of Papua New Guinea, the Chinese in Singapore, and the Europeans resident in Australasia (Burton-Bradley, 1968,1972 ). Since that time further instances have surfaced in this area at the rate of approximately one every 18 months. Although culturally variable, there is a hard-core symptomatology in all of them, based on the self-defined unrelieved insult. There are four discrete periods: (a) a prodromal brooding, during which a resolution may be effected if circumstances permit; (b) explosive homicidal outburst; (c) continuing homicidal drive; and (d) a retrospective claim of amnesia by the ones who survive.

Case Reports: (i) A 35-year-old Caucasian public servant had received no promotion for 10 years. He wrote me a letter in 1967 outlining his claim of differential treatment. He stated that he had been continually overlooked, that colleagues with the same or lesser qualifications had been promoted, and that he had been railroaded into a dead-end position. He declared his empathy with, and total acceptance of, the solution adopted by a laboratory technician in remote Pennsylvania, USA, who had recently ran amok killing six people and wounding six others. This had been reported in great detail in the weekly newspaper. The victims were people in authority over him. I asked the public servant to come and see me, and during the course of interview I detected oversensitivity coupled with anxiety and anger. I formed the opinion that he had a diminished capacity to select and control alternative forms of behaviour. There was, I felt, a serious risk that he would act out the Pennsylvania model. I conferred with his superiors, and it transpired that his promotion was in fact being processed, but at a slow bureaucratic rate. This was speeded up, and the would-be amok runner informed, with dramatic effect in eliminating his brooding. When examined again two years later he was free of all symptoms.

(ii) Another Caucasian amok runner, who was killed during the period of his episode, left behind a letter show. ing how he had modelled his plans on a similar tragedy which took place in remote Canada one month earlier. He had read about it in the newspaper. He had been rated by his victims as a "humbug". He acted out the Canadian model.

These brief observations show that the physician, close acquaintance, or other person in contact with an adult male (usually living alone) who outlines his disaffections in the above fashion should be alerted. The proposed ban on certain classes of firearms, admirable as it may well be, is based on a response to public expectation and not necessarily on fact. It will do little to eliminate such episodes, and gives the impression of seeking a solution merely by closing the door after the horse has bolted. Also, it is unlikely that much help will, or could be, obtained from the media, but such bodies should be adequately informed. But is psychiatric expertise being fully utilised?

The Maho Place Clinic,

Burton G. Burton-Bradley PO Box 111, Port Moresby

Papua New Guinea

\section{References}

Burton-Bradley, B. G. (1968) The amok syndrome in Papua New Guinea. Medical Journal of Australia, 1, 252-256.

(1972) The amok runner in cross-cultural perspective. Indian Journal of Psychialry. 14, 299-305.

"Hypereredism: a morbid state of hostile tension, following provocation, sometimes leading to explosive behaviour out of proportion to the circumstances.

\section{Behaviour Disorder in Childhood Re-assessed}

SIR: We have completed a pilot study of one year's intake of 207 children as new out-patients to a hospital-based department of child and adolescent 
psychiatry. At follow-up, 16 months after the intake began, there were 67 cases closed; these were evaluated by two clinicians, mutually blind to each other's assessments. The assessments were made from recordings of the parents' overall description of their children's present state. Inter-observer disagreement occurred in 5 out of the 46 cases assessed by both.

The interesting result was that response to intervention was greatest with behaviour disorder (76\%) and least with neurotic disorder $(57 \%)$. This is opposite to the generally held view, supported by numerous studies (West \& Farrington, 1977; Mulligan et al, 1963; Richman et al, 1982), that behaviour disorder is difficult to treat and has a poorer prognosis than childhood neurosis (Rutter, 1972; Kovaks et al, 1984).

Perhaps the introduction of a family therapy approach (which always involves the father in our clinic) changes the prognosis compared with more traditional therapeutic approaches. A three-year follow-up of all 207 cases will be completed shortly

\section{Poole General Hospital}

Paul SePping

\section{Poole, Dorset}

St Ann's Hospital

Poole, Dorset

Department of Child \& Adolescent

Psychiatry, Poole

\section{References}

Kovaks, M., Fennberg, L. T. \& Crouse-Novak, M. A. (1984) Depressive disorders of childhood - a longitudinal prospective study of characteristics and recovery. Archives of General Psychiatry, 41, 229.

Murligan, G., Douglas, J. W. B., Hammond, W. A. \& Tizard, J. (1963) Delinquency and symptoms of maladjustment; the findings of a longitudinal study. Proceedings of the Royal Sociely of Medicine, 56, 1083-1086.

Rictiman, N. el al (1982) Preschool to School: A Behavioural Study. London: Academic Press.

RUTTER, M. (1972) Relationship between child and adult psychiatric disorders. Acta Psychiatrica Scandinavica, 48, 3-21.

WEST, D. J. \& FARRINGTON, D. P. (1977) The Delinquent Way of Life. London: Heinemann.

\section{Indecent Exposure - A Report of a Female}

SIR: Indecent exposure is a rare problem in women (O'Connor, 1987), and the few reported cases are generally associated with factors such as hypomanic episodes or alcohol use. We report an ex-nun with a history of inappropriate sexualisation as a young child, referred because of genital exposure.
Case Report: A 36-year-old sales assistant was referred because of feeling depressed and a six-year history of genital exposure, usually to authority figures: for example, the mother superior while living in a convent, and the priest running a therapy centre. She had also exposed in order to get attention when feeling miserable and lonely. The exposure was planned; she would enjoy a response of shock and anger and lie on the floor kicking her legs, talking in a babyish fashion, and hoping to be smacked. She would also make repeated telephone calls, and haunt the front door of her victims (usually women).

The patient's mother had no time for talking, playing, or cuddling with her four children (her husband was a violent man and a heavy drinker), and would masturbate her children to comfort them if they were upset; their only bodily contact was smacking. Her younger brother was impotent as an adult, and our patient had never had a sexual relationship, but enjoyed looking at other women's bodies.

We aimed to help the patient to make friends and to relate normally in a therapeutic community of patients with mainly long-term neuroses, while continuing at work. She managed to keep this job, but made no friends and continued to expose to senior nursing and medical staff.

This report illustrates the lasting damage of inappropriate sexualisation in a young child (Mzarek \& Kempe, 1981). She had no experience of affectionate non-sexual handling, and attached erotic sensations to non-sexual infantile behaviour and so regressed in this way. This was sexual abuse from stressed parents who did not derive sexual gratification themselves but were in need of help with their family. Early intervention in such families is very important (Werner, 1985).

Diana Cassell JOAN GOMEZ

The Gordon Hospital

Bloomburg Street

London SWI

\section{References}

MrAzEx, P. B. \& KEMPE, C. H. (1981) Sexually Abused Children and their Families. Oxford: Pergamon.

O'CONNoR, A. A. (1987) Female sex offenders. British Journal of Psychiatry, 150, 615-620.

WERNER, E. E. (1985) Stress and protective factors in children's lives In Longitudinal Studies in Child Psychology and Psychiatry (ed. Arnicol). Chichester: John Wiley \& Sons.

\section{Mania Following Head Injury}

SIR: We read the report by Clarke \& Davison, (Journal, June 1987, 150,841-844) and would like to report another example.

Case Report: A 38-year-old self-employed married businessman was admitted in May 1987 for investigation and 